\title{
EXPERIMENTAL STUDY ON INDOOR THERMAL ENVIRONMENT AND VENTILATION PERFORMANCE OF FLOOR-SUPPLY DISPLACEMENT VENTILATION SYSTEM 全面床吹出し置換空調システムの室内熱環境及び換気性能に関する実験研究
}

\author{
Takashi AKIMOTO*, Tatsuo NOBE**, Shin-ichi TANABE*** and Ken-ichi KIMURA**** \\ 秋元 孝之, 野部達夫, 田辺新一，木村建一
}

\begin{abstract}
Results of laboratory measurements on the thermal performance of the floor-supply displacement ventilation system in comparison with a displacement ventilation system with sidewall mounted diffuser and a ceiling based distribution system are described. The experiments were performed in a controlled chamber configured to resemble a modern office space with modular workstation furniture and partitions. In addition to detailed measurements of temperature, air velocity, and tracer gas concentration, a skin temperature controlled thermal manikin was used to evaluate the non-uniformity of thermal environments produced by these systems.

Thermal stratification was observed in both of the displacement ventilation systems which produced greater air temperature differences than the ceiling based system. Under the conditions of the appropriate supply air volume against indoor heat load the displacement ventilation systems could be operated to maintain acceptable thermal comfort and high ventilation efficiency in the occupant zone of the space, at the same time taking advantage of the temperature stratification to achieve energy savings in air conditioning.
\end{abstract}

keywords: ventilation efficiency, thermal comfort, displacement ventilation 換気効率、熱的快適性、置換換気

\section{INTRODUCTION}

The displacement ventilation system, that realizes high ventilation efficiency, has been one of the main topics in the HVAC field in recent years. This system has been gaining popularity in Scandinavia not only for large spaces with high ceilings, such as auditoriums and assembly halls, but also for medium sized office buildings. In this system, supply air of a temperature several degrees below room temperature is introduced at very low velocity through air supply devices of large area near floor level and returned at ceiling level. The system can achieve considerably higher ventilation efficiency in comparison with what is theoretically possible with the complete mixing system ${ }^{1)}$. Displacement ventilation is characterized by two distinct horizontal zones with different airflow patterns. The lower zone contains cooler and fresher supply air. Where the air moves upward above heat sources, ambient air is entrained into the air movement. The upper zone is relatively well mixed and contains warmer air and greater concentrations of space contaminants ${ }^{2}$. However, thermal stratification may cause cold discomfort for the legs and feet in conjunction with warm discomfort at the head level. Actually, some examples of serious local discomfort due to draft and vertical temperature difference were reported in Melikov and Nielsen ${ }^{3)}$ and Melikov et al. ${ }^{4)}$ Wyon and Sandberg ${ }^{5)}$ used a thermal manikin to predict comfort due to displacement ventilation and proposed some equations to assess indoor environment.

The horizontal discharge from a low side wall position has been regarded as the most common air supply configuration of the displacement ventilation system. However, when we have to address the need for greater supply volume without increasing the risk of draft, this could not be considered the most suitable arrangement. Recent publications have described an office displacement ventilation system design, what we call the floorsupply displacement ventilation system, that supplies air through an air permeable carpet over a raised access floor ${ }^{6)}$, ${ }^{\text {) }}$, thus significantly increasing the area of air supply.

The purpose of this study is to identify the indoor thermal environment and ventilation performance of a floor-supply displacement ventilation system in comparison with a displacement ventilation system with sidewall mounted diffuser and a ceiling based distribution system by experiment in a

\footnotetext{
* Senior Engineer, Shimizu Corporation, Tokyo, M. Sc.

** Manager, Shimizu Corporation, Tokyo, Dr. Eng.

*** Assoc. Prof., Ochanomizu University, Tokyo, Dr. Eng.

**** Prof., Waseda University, Tokyo, Dr. Eng.
}

清水建設(姝)設備本部 工修

清水建設侏設計本部 工博

お茶の水女子大学生活科学部 助教授・工博

早稲田大学理工学部 教授・工博 
simulated office space: In addition to detailed measurements of temperature, air velocity, and tracer gas concentration, a skin temperature controlled thermal manikin ${ }^{8)}$ was used to evaluate the non-uniformity of thermal environments produced by these systems.

\section{EXPERIMENTAL METHODS}

\subsection{Experimental Chamber}

All experiments were performed in an office environmental test chamber of Ochanomizu University ${ }^{9}$ ) in June $1995 . \quad$ The chamber was designed to resemble a modern office space with modular workstation furniture and partitions as shown in Figure 1 . The floor except for the circumferential area of 150-200 mm width was fully covered with the air permeable carpet over a raised access floor, producing a $300 \mathrm{~mm}$ high subfloor plenum. Figure 2 presents the concept of the floor-supply displacement ventilation system. The air permeable tile carpet was composed of carpet fiber, a meshed intermediate layer, and a foundation layer with a total thickness of $7 \mathrm{~mm}$. The air flow resistance of the carpet was about $14 \mathrm{~Pa}$ when the face air velocity of supply air was $0.01 \mathrm{~m} / \mathrm{s}$ (calculated using measured air volume through the carpet). The underfloor space was used as a pressurized plenum chamber for air supply, to one side of which a supply duct was connected to realize the floor-supply displacement ventilation system. For the displacement ventilation system with the sidewall mounted diffuser, an air supply unit was placed at the comer of the chamber connected to a supply duct. For the conventional ceiling based system, supply air was diffused through an inlet on the ceiling connected to a supply duct. For all systems, air is exhausted at the ceiling level through two return air grilles. Four electric heaters on each desk were provided to simulate heat load sources for experiments.

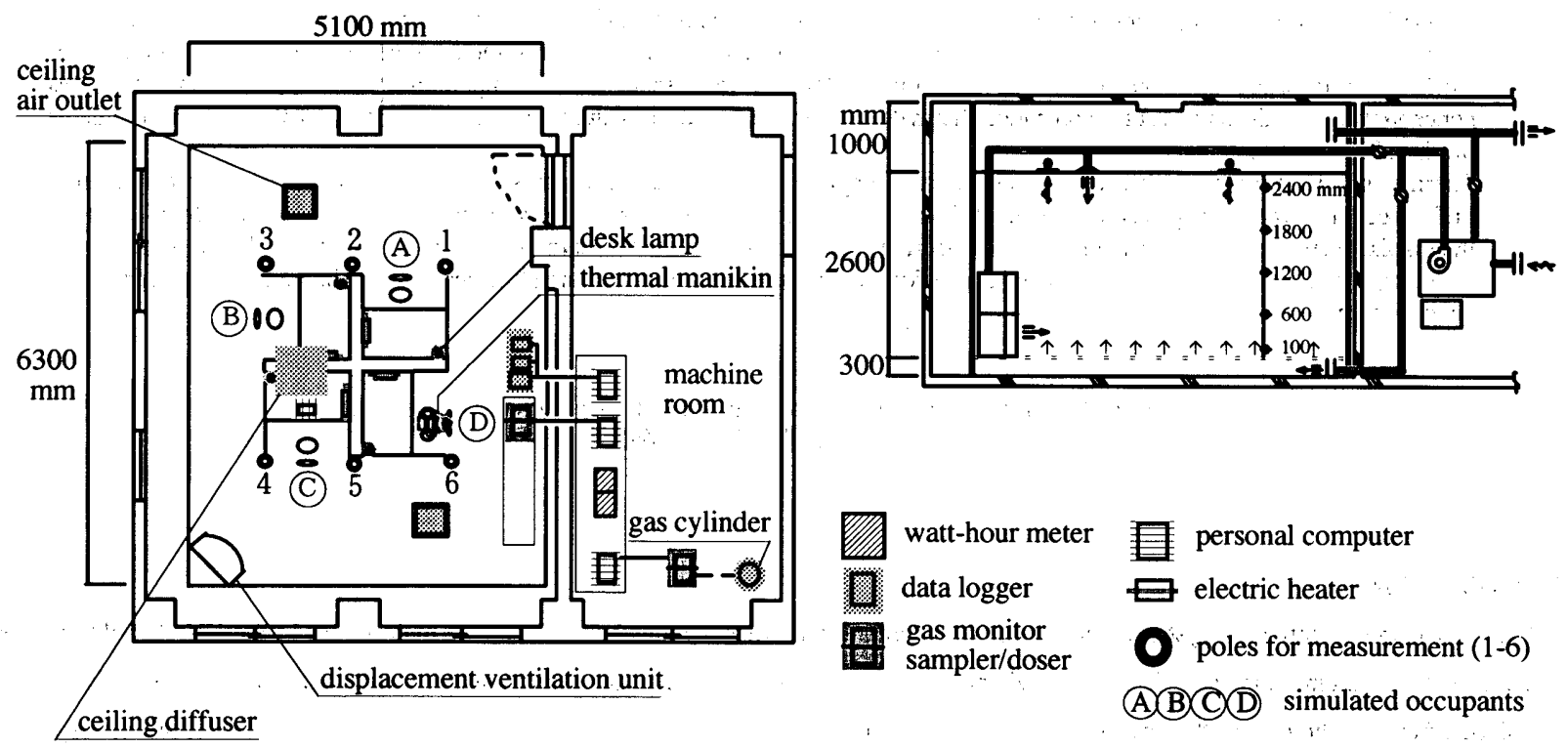

Figure 1 Experimental chamber

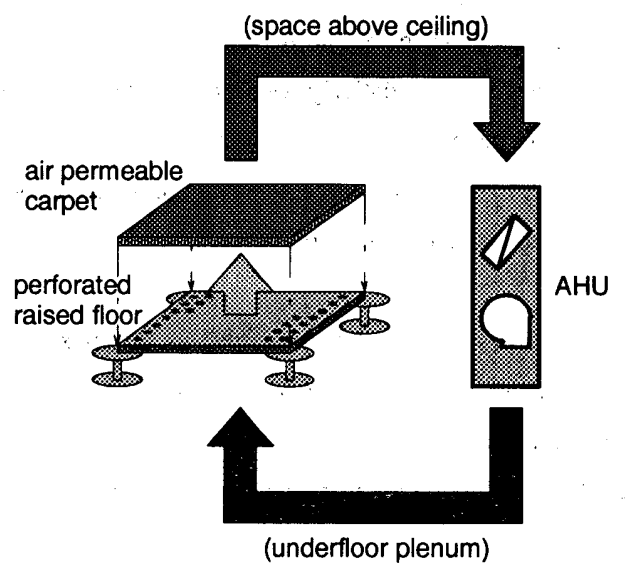

Figure 2 Floor-supply displacement ventilation system

\subsection{Measurement Methods}

Measurement methods are presented in Table 1. Room air temperatures were measured at $0 \mathrm{~m}, 0.1 \mathrm{~m}, 0.3 \mathrm{~m}, 0.6 \mathrm{~m}, 1.1 \mathrm{~m}, 1.6 \mathrm{~m}, 2.0 \mathrm{~m}, 2.3 \mathrm{~m}$, $2.5 \mathrm{~m}$, and $2.6 \mathrm{~m}$ above floor level at six points (poles 1-6). Air velocities were measured at $0 \mathrm{~m}, 0.1 \mathrm{~m}, 0.6 \mathrm{~m}, 1.1 \mathrm{~m}, 1.8 \mathrm{~m}$, and $2.4 \mathrm{~m}$ above floor level 
at four points (points A-D). Local mean age of air was observed at $0.1 \mathrm{~m}, 0.6 \mathrm{~m}, 1.2 \mathrm{~m}, 1.8 \mathrm{~m}$, and $2.4 \mathrm{~m}$ above floor level at point $\mathrm{D}$ for the vertical distribution. At the same time, that was measured at $1.2 \mathrm{~m}$ above floor level at points $\mathrm{A}, \mathrm{B}, \mathrm{C}$, and $\mathrm{D}$ to see the horizontal distribution. The skin temperature controlled thermal manikin was used to evaluate the non-uniform thermal environments. Local mean age of air was obtained using a tracer gas $\left(\mathrm{SF}_{6}\right)$ decay method. Two or three sets of multi-gas monitors and multi-point sampler/dosers $(\mathrm{B} \& \mathrm{~K} 1302,1303)$ were used to measure the concentration of tracer gas. For each test, local mean age of air was calculated using measured concentration. Local Mean Age of Air ${ }^{10)}\left(\bar{\tau}_{p}\right)$ for tracer decay method is defined here as follows.

$$
\begin{aligned}
& \bar{\tau}_{\mathrm{p}}=\int_{0}^{\infty} \frac{\mathrm{C}_{\mathrm{p}}(\mathrm{t})}{\mathrm{C}_{\mathrm{p}}(0)} \mathrm{dt} \\
& \text { where } \quad C_{p}(t) \quad \text { : concentration of tracer gas at point } \mathrm{p} \text { at time } \mathrm{t}\left[\mathrm{m}^{3} / \mathrm{m}^{3}\right] \\
& \mathrm{C} p(0) \quad \text { : initial concentration of tracer gas for tracer decay method }\left[\mathrm{m}^{3} / \mathrm{m}^{3}\right]
\end{aligned}
$$

Table 1 Measurement methods

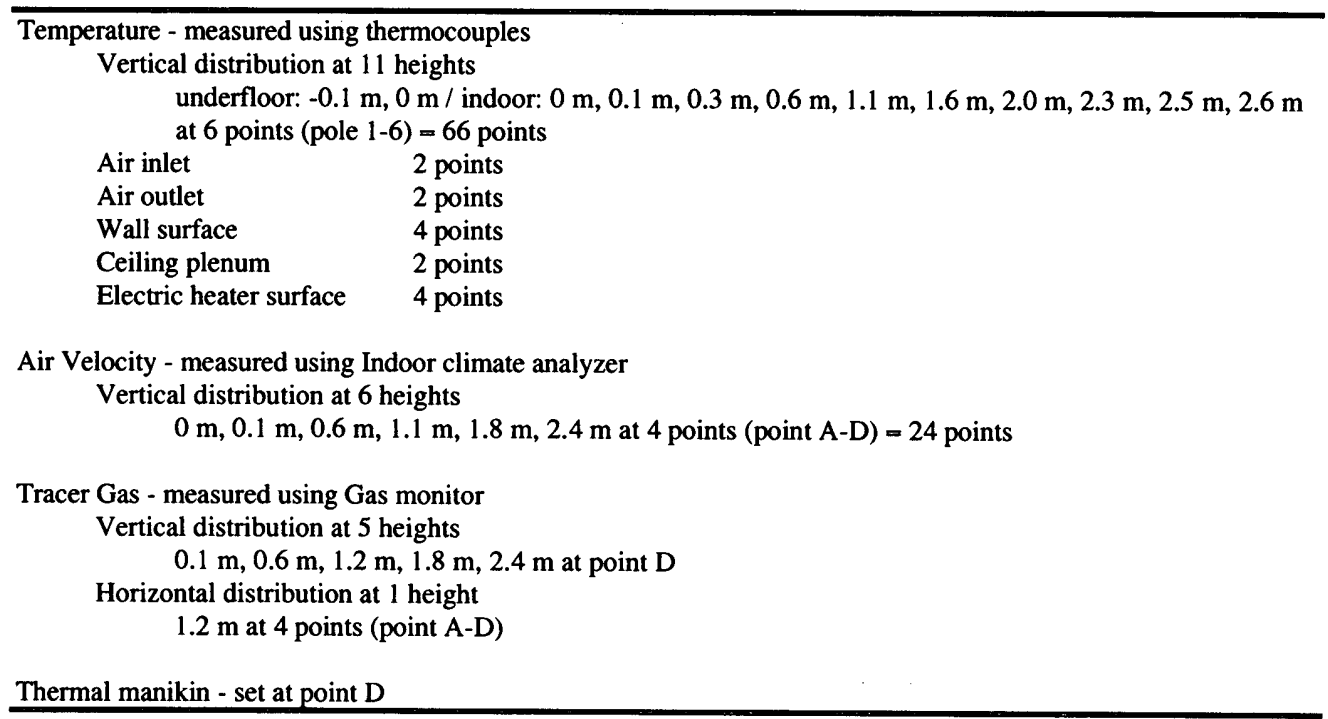

\subsection{Experimental Conditions}

Experimental conditions are listed in Table 2. Supply air volume was controlled to be constant at either $800 \mathrm{~m}^{3} / \mathrm{h}$ or $400 \mathrm{~m}^{3} / \mathrm{h}$. Supply air temperature was controlled to maintain $25^{\circ} \mathrm{C}$ room air temperature at $1.2 \mathrm{~m}$ above floor level at point $\mathrm{D}$. For air change efficiency measurement, $100 \%$ outside air was introduced to the chamber. Room air pressure was controlled to be slightly positive compared to the adjacent room to prevent air infiltration to the chamber. Four electric heaters to simulate workstation on the desks were installed. Four task lighting and ceiling fixtures were illuminated during the experiments. Air temperature of annular space, a plenum wall construction of two exterior chamber walls, was steadily controlled throughout the experiments to prevent undesirable heat exchange with the outside.

Table 2 Experimental conditions

\begin{tabular}{c|c|c|c}
\hline Case & System & Supply air volume & Heat load condition \\
\hline F-1 & Floor-supply displacement ventilation system & $800 \mathrm{~m}^{3} / \mathrm{h}^{* 1}$ & $1600 \mathrm{~W}\left(50 \mathrm{~W} / \mathrm{m}^{2}\right)$ \\
\hline F-2 & Floor-supply displacement ventilation system & $800 \mathrm{~m}^{3} / \mathrm{h}$ & $800 \mathrm{~W}\left(25 \mathrm{~W} / \mathrm{m}^{2}\right)$ \\
\hline F-3 & Floor-supply displacement ventilation system & $400 \mathrm{~m}^{3} / \mathrm{h}^{2 /}$ & $800 \mathrm{~W}\left(25 \mathrm{~W} / \mathrm{m}^{2}\right)$ \\
\hline D-1 & Displacement ventilation system with sidewall mounted diffuser & $800 \mathrm{~m} / 3$ & $1600 \mathrm{~W}\left(50 \mathrm{~W} / \mathrm{m}^{2}\right)$ \\
\hline D-2 & Displacement ventilation system with sidewall mounted diffuser & $800 \mathrm{~m} / \mathrm{h}$ & $800 \mathrm{~W}\left(25 \mathrm{~W} / \mathrm{m}^{2}\right)$ \\
\hline D-3 & Displacement ventilation system with sidewall mounted diffuser & $400 \mathrm{~m}^{3} / \mathrm{h}$ & $800 \mathrm{~W}\left(25 \mathrm{~W} / \mathrm{m}^{2}\right)$ \\
\hline C-1 & Ceiling based air distribution system & $800 \mathrm{~m} / \mathrm{h}$ & $1600 \mathrm{~W}\left(50 \mathrm{~W} / \mathrm{m}^{2}\right)$ \\
\hline C-2 & Ceiling based air distribution system & $800 \mathrm{~m}^{3} / \mathrm{h}$ & $800 \mathrm{~W}\left(25 \mathrm{~W} / \mathrm{m}^{2}\right)$ \\
\hline C-3 & Ceiling based air distribution system & $400 \mathrm{~m} / 3$ & $800 \mathrm{~W}\left(25 \mathrm{~W} / \mathrm{m}^{2}\right)$ \\
\hline
\end{tabular}

\footnotetext{
${ }^{* 1} 9.6$ room air changes per hour $\quad{ }^{* 2} 4.8$ room air changes per hour
} 


\section{RESULTS}

\subsection{Temperature Distribution}

Vertical air temperature distribution is presented in Figures 3, 4, and 5: Data shown in the figures are averaged values measured at poles 1,$2 ; 3$, and 6. Because in Cases D-1, D-2, and D-3 of the displacement ventilation system with sidewall mounted diffuser, the data measured at poles 4 and 5 were pretty much influenced by the direct supply air flow from the air supply unit set quite close to these poles, which were not considered to be suitable for the occupant space. Thermal stratification was observed as greater air temperature differences between lower and higher parts of the room for both of the floor-supply displacement ventilation system (Cases F-1, F-2, and F-3) and the displacement ventilation system with sidewall mounted diffuser (Cases D-1, D-2, and D-3) in comparison to the ceiling based system (Cases C-1, C-2, and C-3). There were more or less one degree temperature differences between both sides of the air permeable tile carpet of the floor-supply displacement ventilation system .

For vertical air temperature differences in the occupied space, air temperature differences 'between the $0.1-\mathrm{m}$ and $1.1-\mathrm{m}$ levels or 1.6-m levels' are presented in Figure 6. They are averaged values at poles 1, 2,3, and 6, as described before. A large vertical temperature difference that may cause local thermal discomfort was observed in several cases for both of the displacement ventilation systems. The floor-supply displacement ventilation system showed greater temperature differences compared to that of the displacement ventilation system with sidewall mounted diffuser for $800 \mathrm{~m}^{3} / \mathrm{h}$ supply air volume with $25 \mathrm{~W} / \mathrm{m}^{2}$ heat load and $400 \mathrm{~m}^{3} / \mathrm{h}$ supply air volume with $25 \mathrm{~W} / \mathrm{m}^{2}$ heat load. ISO Standard $7730^{11)}$ recommends that the vertical air temperature difference should be less than $3^{\circ} \mathrm{C}$ between the $0.1-\mathrm{m}$ and $1.1 \mathrm{-m}$ levels, and ASHRAE Standard $55-1992^{12)}$ specifies less than $3^{\circ} \mathrm{C}$ between the

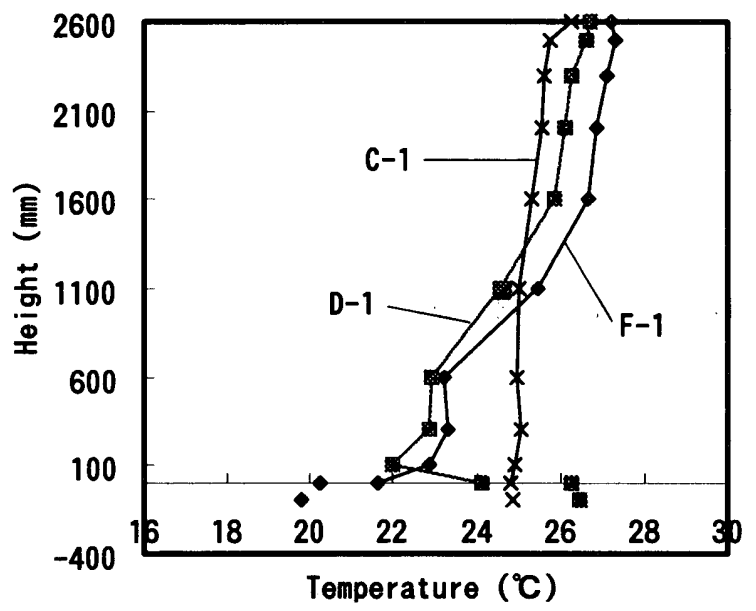

Figure 3 Vertical air temperature distribution: $800 \mathrm{~m}^{3} \mathrm{~h}, 50 \mathrm{~W} / \mathrm{m}^{2}$

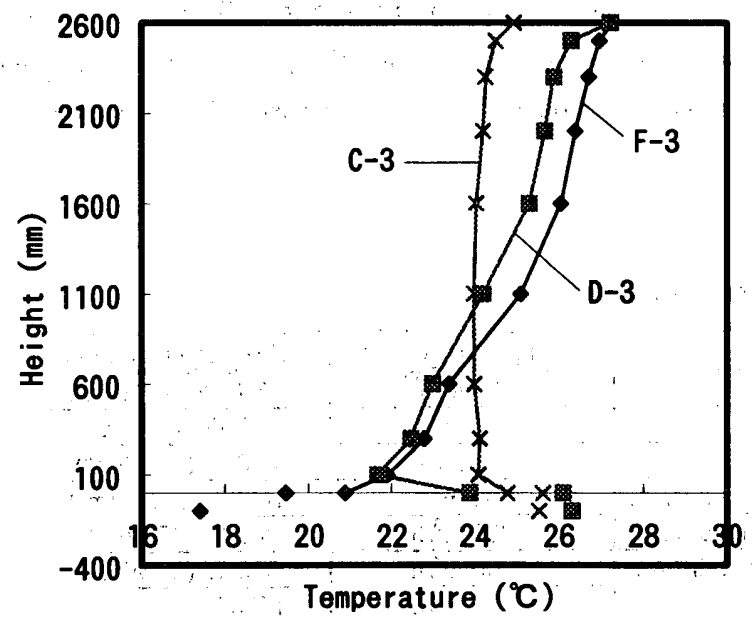

Figure 5 Vertical air temperature distribution: $400 \mathrm{~m}^{3} / \mathrm{h}, 25 \mathrm{~W} / \mathrm{m}^{2}$

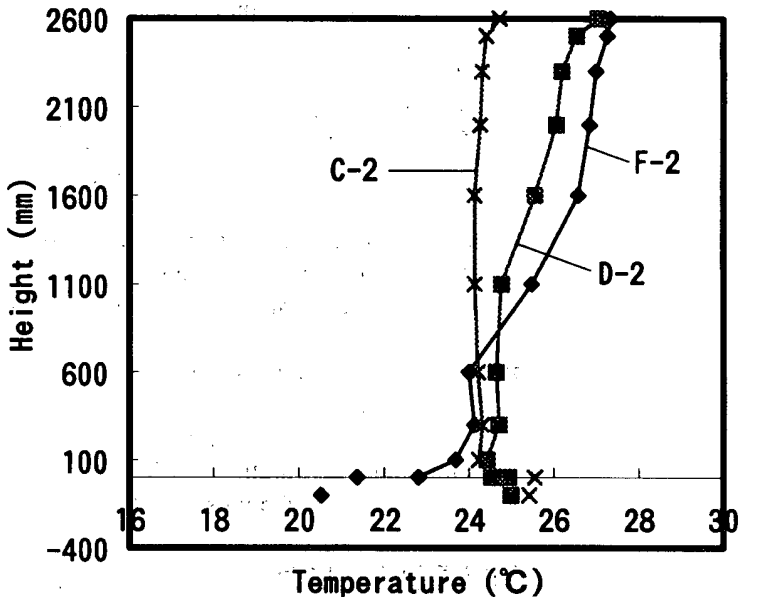

Figure 4 Vertical air temperature distribution: $800 \mathrm{~m}^{3} \mathrm{~h}, 25 \mathrm{~W} / \mathrm{m}^{2}$.

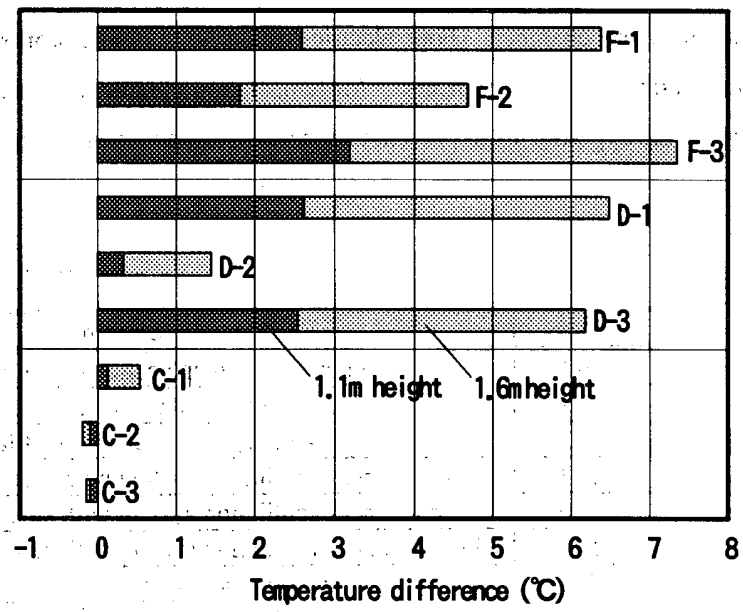

Figure 6 Air temperature differences in occupied space: deviation from $0.1 \mathrm{~m}$-level temperature 
0.1-m and 1.7-m levels. Among the displacement ventilation systems, only two cases of a large supply air volume with a small heat load (Cases F-2 and D-2) could meet the qualification of the ASHRAE standard. The limits of local discomfort recommended in the standards are based on conventional complete mixing systems. However, care must be taken to choose appropriate supply air volumes in applying the displacement ventilation systems to the actual space to prevent local discomfort.

In Table 3, measured heat load, supply air temperature, return air temperature, and heat balance are shown for each case.

Table 3 Heat balance

\begin{tabular}{c|c|c|c|c}
\hline Case & Measured heat load & Supply air temperature & Return air temperature & Heat balance \\
\hline F-1 & $1538 \mathrm{~W}$ & $21.5^{\circ} \mathrm{C}$ & $27.0^{\circ} \mathrm{C}$ & $1450 \mathrm{~W}$ \\
\hline F-2 & $973 \mathrm{~W}$ & $22.7^{\circ} \mathrm{C}$ & $27.0^{\circ} \mathrm{C}$ & $1140 \mathrm{~W}$ \\
\hline F-3 & $865 \mathrm{~W}$ & $21.0^{\circ} \mathrm{C}$ & $26.7^{\circ} \mathrm{C}$ & $750 \mathrm{~W}$ \\
\hline $\mathrm{D}-1$ & $1584 \mathrm{~W}$ & $19.0^{\circ} \mathrm{C}$ & $26.2^{\circ} \mathrm{C}$ & $1900 \mathrm{~W}$ \\
\hline $\mathrm{D}-2$ & $765 \mathrm{~W}$ & $23.2^{\circ} \mathrm{C}$ & $26.0^{\circ} \mathrm{C}$ & $740 \mathrm{~W}$ \\
\hline $\mathrm{D}-3$ & $755 \mathrm{~W}$ & $18.6^{\circ} \mathrm{C}$ & $25.8^{\circ} \mathrm{C}$ & $950 \mathrm{~W}$ \\
\hline $\mathrm{C}-1$ & $1642 \mathrm{~W}$ & $20.3^{\circ} \mathrm{C}$ & $25.7^{\circ} \mathrm{C}$ & $1430 \mathrm{~W}$ \\
\hline $\mathrm{C}-2$ & $764 \mathrm{~W}$ & $\left(21.6^{\circ} \mathrm{C}\right)^{*}$ & $24.5^{\circ} \mathrm{C}$ & $(764 \mathrm{~W})^{*}$ \\
\hline $\mathrm{C}-3$ & $753 \mathrm{~W}$ & $17.2^{\circ} \mathrm{C}$ & $24.5^{\circ} \mathrm{C}$ & $960 \mathrm{~W}$ \\
\hline
\end{tabular}

${ }^{*}$ Estimated using supply air volume and measured heat load because of imperfect measurement of supply air temperature

\subsection{Air Velocity Distribution}

Vertical air velocity distribution is presented in Figure 7 for $800 \mathrm{~m}^{3} / \mathrm{h}$ supply air volume with $50 \mathrm{~W} / \mathrm{m}^{2}$ heat load and in Figure 8 for $400 \mathrm{~m}^{3} / \mathrm{h}$ supply air volume with $25 \mathrm{~W} / \mathrm{m}^{2}$ heat load respectively. Plotted points are the averaged values of four measurement points at the same vertical height. The floor-supply displacement ventilation system (Cases F-1 and F-3) produced an uniform low air velocity (less than $0.1 \mathrm{~m} / \mathrm{s}$ ) at each measurement height. In comparison to that, a rather high air velocity near the floor $(0.1-\mathrm{m}$ level) was observed for the displacement ventilation system with sidewall mounted diffuser (Cases D-1 and D-3). The ceiling based system (Cases C-1 and C-3), however, showed a non-uniform distribution and a much higher air velocity near the ceiling. It is expected that the floor-supply displacement ventilation system will meet the need for a greater air supply volume without increasing the risk of draft discomfort.

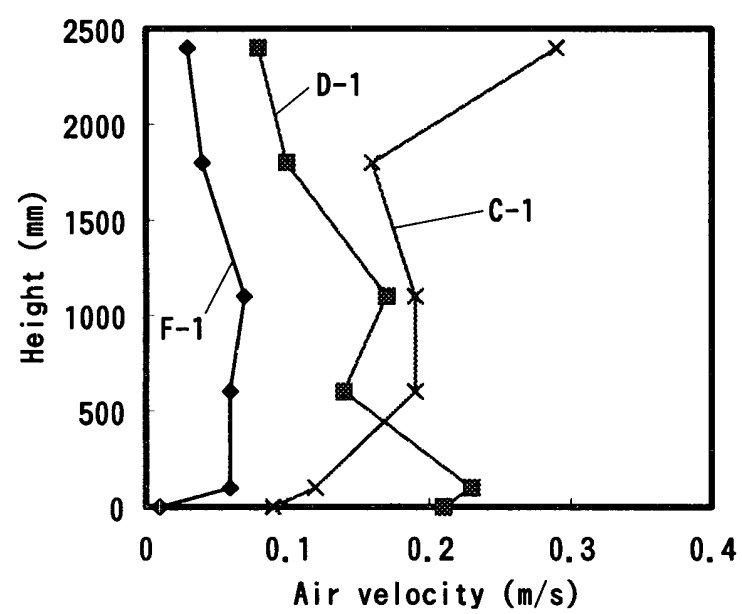

Figure 7 Vertical air velocity distribution: $800 \mathrm{~m}^{3} \mathrm{~h}, 50 \mathrm{~W} / \mathrm{m}^{2}$

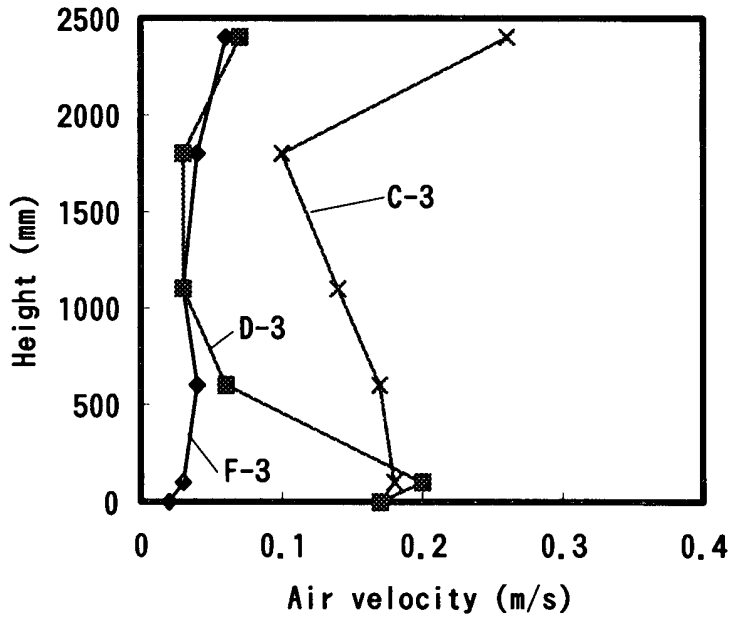

Figure 8 Vertical air velocity distribution: $400 \mathrm{~m}^{3} / \mathrm{h}, 25 \mathrm{~W} / \mathrm{m}^{2}$

\subsection{Measurements with Thermal Manikin}

Figure 9 presents the measured skin surface temperatures at 16 parts of the thermal manikin for $800 \mathrm{~m}^{3} / \mathrm{h}$ supply air volume with $50 \mathrm{~W} / \mathrm{m}^{2}$ heat load. The thermal manikin was sitting in one of workstations (point D) during the experiments. Plotted points are the averages of measured values for 10 minutes. It was observed that measured skin surface temperatures of both of the displacement ventilation systems were slightly lower except in the area of the 'pelvis' than those of the ceiling based system. However, this is not considered too low to cause local thermal discomfort. 


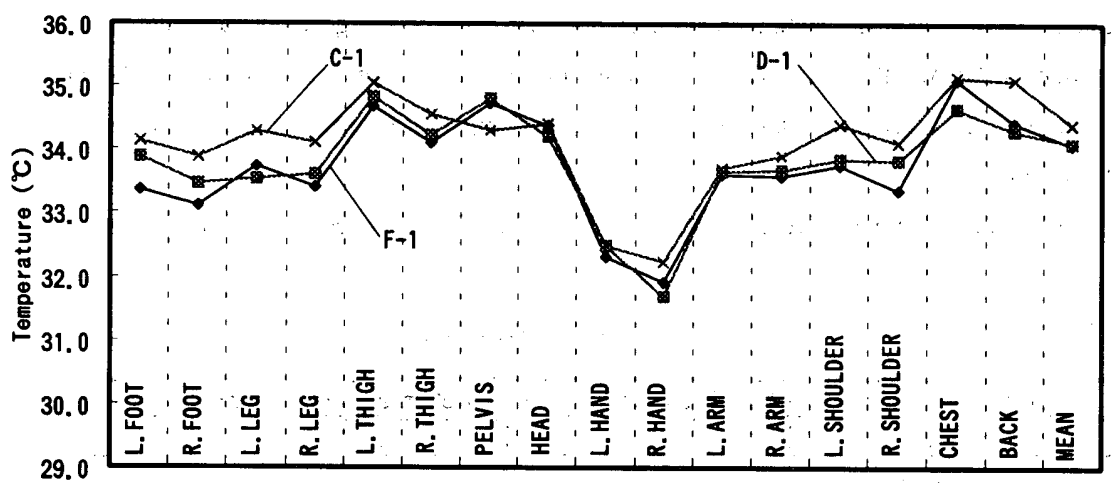

Figure 9 Local skin temperature of thermal manikin: $800 \mathrm{~m}^{3} \mathrm{~h}, 50 \mathrm{~W} / \mathrm{m}^{2}$

\subsection{Local Mean Age of Air}

Vertical distribution of local mean age of air is presented in Figure 10 for $800 \mathrm{~m}^{3} / \mathrm{h}$ supply air volume with $50 \mathrm{~W} / \mathrm{m}^{2}$ heat load and in Figure 11 for $400 \mathrm{~m}^{3} / \mathrm{h}$ supply air volume.with $25 \mathrm{~W} / \mathrm{m}^{2}$ heat load respectively. In most cases in both of the displacement ventilation systems, the effect of piston flow is evident in the lower part of the room (Cases F-1, D-1, and F-3). In the displacement ventilation system with sidewall mounted diffuser for $400 \mathrm{~m}^{3} / \mathrm{h}$ supply air volume with $25 \mathrm{~W} / \mathrm{m}^{2}$ heat load (Case D-3), however, local mean age of air in the lower part of the room was relatively greater. It could be explained that there was salient vertical down-draft along the walls due to the effect of gravity in the cooled air near the surface for this particular case. This downward flow along the wall compensated the surplus air that was not extracted from the room through ceiling air outlets. Since the data were only measured at point $\mathrm{D}$, further investigation will be required to clarify the exact reason of this observation. Horizontal distribution of local mean age of air at $1.2 \mathrm{~m}$ above floor level was quite uniform in each cases, incidentally. For the ceiling based system, there were a little vertical differences in local mean age of air (Cases $\mathrm{C}_{-}-1$ and $\mathrm{C}-3$ ).

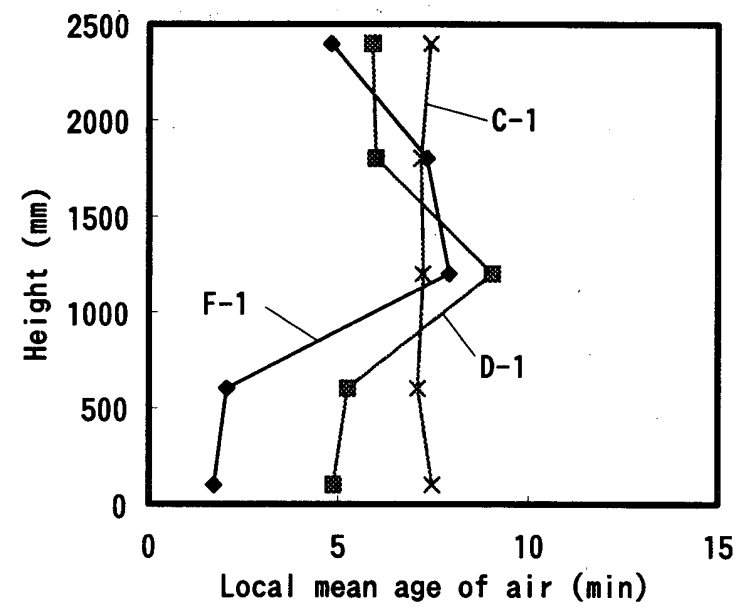

Figure 10 Vertical local mean age of air distribution: $800 \mathrm{~m}^{3} / \mathrm{h}, 50 \mathrm{~W} / \mathrm{m}^{2}$

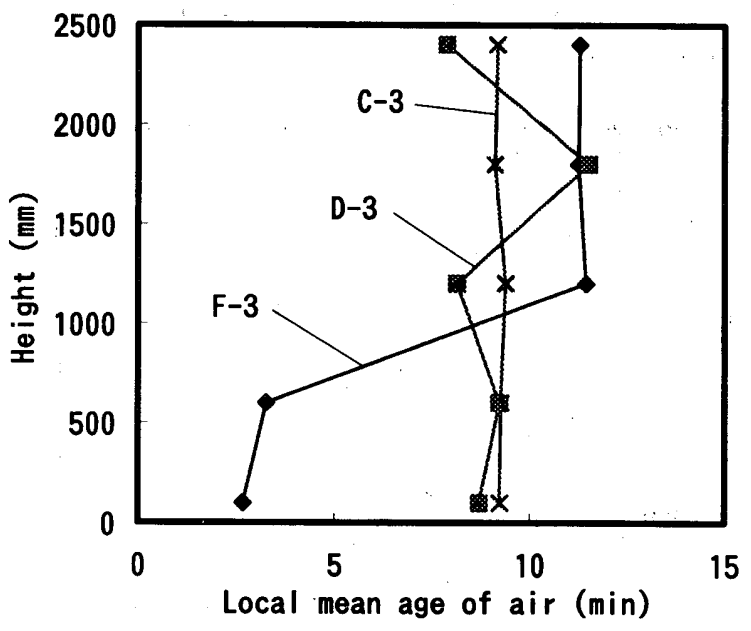

Figure 11 Vertical local mean age of air distribution: $400 \mathrm{~m}^{3} \mathrm{~h}, 25 \mathrm{~W} / \mathrm{m}^{2}$

\subsection{Contaminant removal}

Time series of tracer gas concentrations measured at three different heights $(0.1 \mathrm{~m}, 1.2 \mathrm{~m}$, and $2.4 \mathrm{~m})$ at point $\mathrm{D}$ are presented in Figures 12 for 800 $\mathrm{m}^{3} / \mathrm{h}$ supply air volume with $50 \mathrm{~W} / \mathrm{m}^{2}$ heat load. Tracer gas was dosed at the mouth of the thermal manikin sitting in one of the workstations (point $\mathrm{D}$ ). The displacement ventilation systems hardly had the room air mixed and contaminants were exhausted to the upper space even from the results with $\mathrm{SF}_{6}$ measurements. It is observed that tracer gas concentrations at 1.2-m level of the floor-supply displacement ventilation system (Case F-1). were quite low, almost less than five ppm. However, the other plots at $0.1 \mathrm{~m}$ and $2.4 \mathrm{~m}$ showed higher concentrations and were unstable. Presumably, this unstability was considered due to the use of $\mathrm{SF}_{6}$, known as 'cold' gas ${ }^{6}$, whose density is greater than the air, mixing itself with the air below the dosing point. If there was no close thermal flow, $\mathrm{SF}_{6}$ could have spread in all directions resulting in high or low local concentrations. The other kind of mixed gas which 


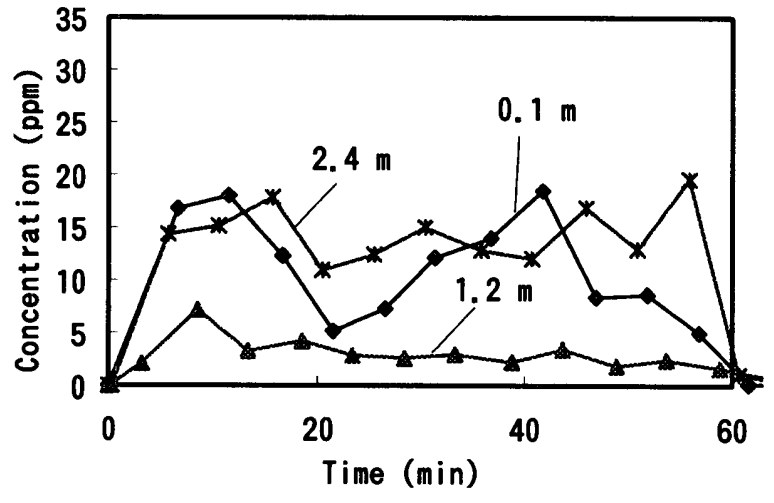

a) Case F-1

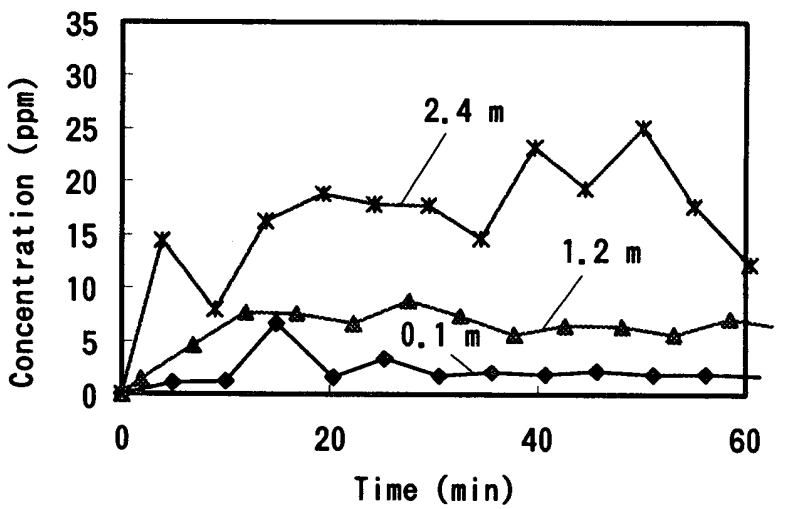

b) Case D-1

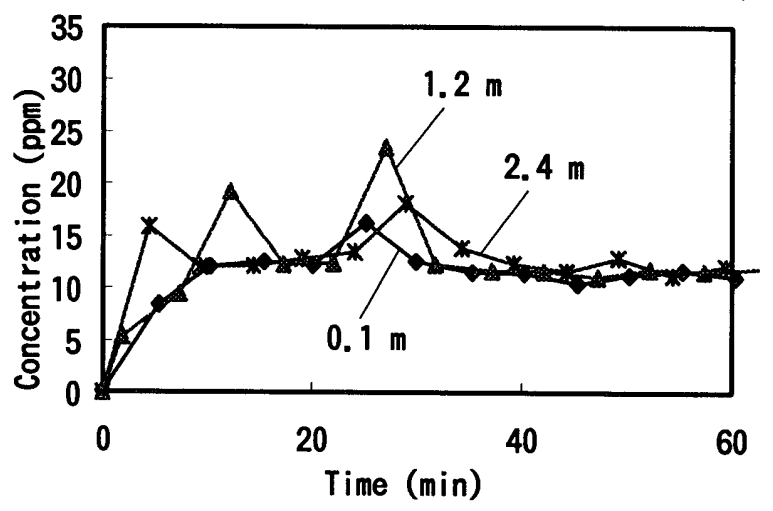

c) Case C-1

Figure 12 Tracer gas concentration at point $D$

density and temperature are similar to the exhalation should be used to investigate the influence of the human respiration exactly in future experiments. For the displacement ventilation system with sidewall mounted diffuser (Case D-1), tracer gas concentrations at 1.2-m level were not so low as the floorsupply displacement ventilation system. It could be explained that relatively higher air velocity below $1.2-\mathrm{m}$ level influenced $\mathrm{SF}_{6}$ not to go down to the floor with its temperature in this case. Also, possibly existing downward thermal flow near the measurement point, as mentioned before, might have caused higher concentration. The concentrations at three different heights of the ceiling based system (Case $\mathrm{C}-1$ ) were relatively uniform and almost all of them fell within the range between 10 and $20 \mathrm{ppm}$.

\section{DISCUSSION}

In most of the environmental chambers, the entire floor is used for air supply to realize high ventilation performance with low air velocity. The floor-supply displacement ventilation system produces a suitable environment in a room with supply air through a perforated raised floor with air permeable carpet in the same manner. When a high air volume is required to get rid of high heat loads, for example, the air supplied from a very large area does not cause high velocities above the floor, thus making it possible to reduce the risk of draft in the occupied zone. Besides, there is still the advantage of cooling energy savings from thermal stratification with high ventilation performance even under the conditions where air volume is high. Furthermore, air supply from the entire floor allows for improved flexibility, whereas the floor-supply system with independent diffusers requires the space immediately above the diffuser grille to be wide open.

It is considered that more or less one degree temperature difference between both sides of the air permeable tile carpet of the floor-supply displacement ventilation system as observed in Figures 3, 4, and 5 are one of the advantages of this system, because this system could have a part of indoor heat load compensated not only by convection but also by conduction heat transfer. Furthermore, one could have the supply air temperature higher because of the radiation effect caused by the carpet surface temperature slightly lower than the air temperature of the occupied space. Fitzner ${ }^{13)}$ reported that when a cooled ceiling is applied to the displacement ventilation system, the wall temperature becomes lower than the air temperature along the entire wall and the downward flow from the ceiling reaches the floor. It is considered that the floor-supply displacement ventilation system would make the wall temperature lower, as well. In this case, the correct position of a temperature sensor is important.

\section{CONCLUSIONS}


Measurements have been made on the performance of a floor-supply displacement ventilation system in comparison with a displacement ventilation system with sidewall mounted diffuser and a ceiling based distribution system to obtain temperature and air velocity distributions, and local mean age of air in an environmental chamber simulating an office space. The experiments using thermal manikin were also performed. The major conclusions are as follows:

1. Thermal stratification was observed as greater air temperature differences in both of the displacement ventilation systems than in the ceiling based system.

2. Only the cases of a large supply air volume $\left(800 \mathrm{~m}^{3} / \mathrm{h}\right)$ with a small heat load $\left(25 \mathrm{~W} / \mathrm{m}^{2}\right)$ with the displacement ventilation systems could meet the ASHRAE standard in terms of vertical temperature difference.

3. The floor-supply displacement ventilation system showed greater vertical air temperature differences than the displacement ventilation system with sidewall mounted diffuser except for $800 \mathrm{~m}^{3} / \mathrm{h}$ supply air volume with $50 \mathrm{~W} / \mathrm{m}^{2}$ heat load.

4. The floor-supply displacement ventilation system produced an uniform low air velocity at each measurement height. Compared to that, rather high air velocity near the floor was observed for the displacement ventilation system with sidewall mounted diffuser. The ceiling based system showed nonuniform distribution and its air velocity near the ceiling was much higher than the other systems.

5. Measured skin surface temperatures of the thermal manikin with both of the displacement ventilation systems were slightly lower except in the area of the 'pelvis' than in the case of the ceiling based system.

6. Local mean age of air of the floor-supply displacement ventilation system was lower than the other systems especially in the lower part of the room.

7. The floor-supply displacement ventilation system could be operated to share a part of indoor heat load not only by convection but also by conduction heat transfer through the carpet floor.

\section{ACKNOWLEDGMENTS}

The authors would like to express sincere thanks to Miss Reiko Hasebe of Waseda University and Dr. Yoshihisa Takebayashi of Shimizu Corporation for their efforts on this study. A part of this study was presented at INDOOR AIR '96, Nagoya.

\section{REFERENCES}

1) Sandberg, M., and C. Blomqvist. 1989. “Displacement Ventilation Systems in Office Rooms.” ASHRAE Transactions, Vol: 95, Pt. 2, pp. 1041-1049.

2) Mathisen, H.M. 1989. “Case Studies of Displacement Ventilation in Public Halls.” ASHRAE Transactions, Vol. 95, Part 2, p.p. $1018-1027$.

3) Melikov, A.K., and J.B. Nielsen. 1989. "Local. Thermal Discomfort due to Draft and Vertical Temperature Difference in Rooms with Displacement Ventilation." ASHRAE Transactions, Vol. 95, Pt. 2, pp. 1050-1057.

4) Melikov, A.K., G. Langkilde, and B. Derbiszewski. 1990. "Airflow Characteristics in the Occupied Zone of Rooms with Displacement Ventilation." ASHRAE Transactions, Vol. 96, Pt. 1, pp. 555-563.

5) Wyon, D.P., and M. Sandberg. 1990. “Thermal Manikin Prediction of Discomfort due to Displacement Ventilation.” ASHRAE Transactions, Vol. 96, Pt. 1, pp. 67-75.

6) Olesen, B.W., M. Koganei, G.T. Holbrook, J. Seelen, and J.E. Woods. 1993. "Evaluation of a Vertical Displacement Ventilation System." INDOOR AIR 93, Vol. 5.

7) Akimoto, T., T. Nobe, and Y. Takebayashi. 1995. "Experimental Study on the Floor-Supply Displacement Ventilation System." ASHRAE Transactions, Vol. 101, Pt. 2, pp. 912-925.

8) Tanabe, S., E.A. Arens, F.S. Bauman, H. Zhang, and T.L. Madsen. 1994. "Evaluating Thermal Environments by using a Thermal Manikin with Controlled Skin Surface Temperature." ASHRAE Transactions, Vol. 100, Pt. 1, pp. 39-48.

9) Tanabe, S., K. Kimura, J. Harigaya, and K. Hiraoka. 1993. "Design Outline of the Office Environmental Test Chamber of Ochanomizu University.", Proceedings of SHASE Technical Conference, (in Japanese), Osaka, October.

10) Sutcliffe, H. 1990. A guide to air change efficiency. Technical Note AIVC 28, Air Infiltration and Ventilation Center, February.

11) ISO. 1984. International Standard 7730, Moderate thermal environments - determined of the PMV and PPD indices and specification of the conditions for thermal comfort. Geneva: International Standards Organization.

12) ASHRAE. 1992. ANSI/ASHRAE Standard 55-1992, Thermal environmental conditions for human occupancy. Atlanta: American Society of Heating, Refrigerating, and Air-Conditioning Engineers, Inc.

13) Fitzner, K. 1996. "Displacement Ventilation and Cooled Ceilings, Results of Laboratory Tests and Practical Installations." INDOOR AIR 96, Vol. 1 . 


\section{和文要的}

1.はしめに

高効率の換気を可能とする置換換気による空調方式は、空気調和 分野で注目される技術の1つである。この方式は、これまで北欧に おいてオーディトリアムや集会場等の天井の高い空間だけでなく、 オフィスにも適用されてきた。この方式の特徴は温度成層をつくる ことであり、その一般的な方法は、壁面下部から水平に空気を吹出 すという壁吹出置換空調方式である。この場合、足元高さの低温と 頭部高さの高温による局所不快感を引き起こす可能性がある。これ に対して著者らは、ドラフトの危隃性が少なく、かつ大風量に対応 する方式として、通気性のカーペットとOA フロアを給気の経路と するという全面床吹出置換空調方式を提案し、一部報告した。

本研究では、オフィスを模擬した実験室でこの全面床吹出置換空 調方式の特性を壁吹出置換空調方式、天井吹出空調方式と比較して 室内熱環境、換気性能を評価することを目的としている。

\section{2. 実略方法}

全ての実験は、1995 年 6 月にお茶の水女子大学の環境試験室 にて行った。この試験室はワークステーション、什器、パーティシ ヨンを有し、実際のオフィス空間を模擬したデザインとなっている。 OA フロアの上には、床全面に通気性タイルカーペットを敷設した。 床下空間は、全面床吹出置換空調の給気チャンバとして用いた。壁 吹出置換空調の吹出しユニットは、試験室のコーナー部に設置した。 また、天井吹出空調の給気は天井吹出口（1ケ所）より行った。す ベてのシステムにおいて、排気は天井排気口（2 所）より行った。 熱負荷として各机上の電気ヒーター 4 台を利用した。空気温度は 6 点（ポール1〜6）の床上高さ $0 \mathrm{~m} 、 0.1 \mathrm{~m} 、 0.3 \mathrm{~m} 、 0.6 \mathrm{~m} 、 1.1 \mathrm{~m} 、 1.6 \mathrm{~m}$ 、 $2.0 \mathrm{~m} 、 2.3 \mathrm{~m} 、 2.5 \mathrm{~m} 、 2.6 \mathrm{~m}$ の位置で計測した。気流は 4 点 (点 $\mathrm{A} \sim \mathrm{D}$ ) の床上高さ $0 \mathrm{~m} 、 0.1 \mathrm{~m} 、 0.6 \mathrm{~m} 、 1.1 \mathrm{~m} 、 1.8 \mathrm{~m} 、 2.4 \mathrm{~m}$ の位置で計測した。 局所空気齢は点 $\mathrm{D}$ の床上高さ $0.1 \mathrm{~m} 、 0.6 \mathrm{~m} 、 1.2 \mathrm{~m} 、 1.8 \mathrm{~m} 、 2.4 \mathrm{~m}$ の位 置、また、点 $\mathrm{A} 、 \mathrm{~B} 、 \mathrm{C}$ の床上高さ $1.2 \mathrm{~m}$ の位置で計測した。熱環 境の不均一を評価するために皮唐温制御型のサーマルマネキンを 用いた。局所空気秢はトレーサーガス $\left(\mathrm{SF}_{6}\right)$ の減衰法により導出 した。室内への給気は一定風量に制御した。給気温度は点 $\mathrm{D}$ の床上 高さ $1.2 \mathrm{~m}$ の位置で $25^{\circ} \mathrm{C}$ になるように制御した。給気風量と熱負荷 の組合せは、各吹出しシステムにおいて $\left\lceil 800 \mathrm{~m}^{3} / \mathrm{h}, 50 \mathrm{~W} / \mathrm{m}^{2}\right\rfloor 、\left\lceil 800 \mathrm{~m}^{3} / \mathrm{h}\right.$ 、 $\left.25 W / \mathrm{m}^{2}\right\rfloor 、\left\lceil 400 \mathrm{~m}^{3} / \mathrm{h} 、 25 \mathrm{~W} / \mathrm{m}^{2}\right\rfloor$ の 3 条件とした。

\section{3. 結果}

全面床吹出置換空調と壁吹出置換空調を用いた場合には、天井吹 出空調を用いた場合と比べて室内下部と上部との間に大きな温度 差がみられ、温度成層が確認された。全面床吹出置換空調を用いた 場合、通気性カーペットの両面で $1{ }^{\circ} \mathrm{C}$ 前後の温度差があった。 $\left\lceil 800 \mathrm{~m}^{3} / \mathrm{h} 、 25 \mathrm{~W} / \mathrm{m}^{2}\right\rfloor$ と $\left\lceil 400 \mathrm{~m}^{3} / \mathrm{h} 、 25 \mathrm{~W} / \mathrm{m}^{2}\right\rfloor$ の条件下において、全面 床吹出置換空調を用いた場合の方が壁吹出置換空調を用いた場合 よりも床上 $0.1 \mathrm{~m}$ と $1.1 \mathrm{~m}$ あるいは $1.6 \mathrm{~m}$ の間の温度差が大きかった。 全面床吹出置換空調と壁吹出置換空調を用いた場合、 $\left\lceil 800 \mathrm{~m}^{3} / \mathrm{h}\right.$ 、 25W/m²」の条件下でのみ ASHRAE 55-1992 の上下温度差の推奖值（床 上 $0.1 \mathrm{~m}-1.7 \mathrm{~m}$ 間で $3^{\circ} \mathrm{C}$ 差)の条件を満たした。

全面床吹出置換空調を用いた場合は上下方向の各計測点におけ
る気流は $0.1 \mathrm{~m} / \mathrm{s}$ 以下の低風速であった。これと比較して、壁吹出 置換空調を用いた場合には、床近傍においてかなり風速が高くなっ た。天井吹出空調を用いた場合は天井近傍の風速が他の高さの計測 值と比べて非常に高くなり、不均一な上下分布となった。

実験中、サーマルマネキンを点Dの位置に設置した。全面床吹出 置換空調と壁吹出置換空調を用いた場合、サーマルマネキンの腰以 外の皮渞温度は、天井吹出空調を用いた場合に対し、やや低かった。

全面床吹出置換空調と壁吹出置換空調を用いた場合、ほとんどの 条件下で部屋下部におけるピストン・フローが影著であつたが、

$\left\lceil 400 \mathrm{~m}^{3} / \mathrm{h} 、 25 \mathrm{~W} / \mathrm{m}^{2}\right\rfloor$ の条件下で壁吹出置換空調を用いた場合には部 屋下部における局所空気秢が相対的に高くなった。これは壁近傍の 冷気による下向の気流によるものとも考えられるが、この現象を解 明するためにはさらなる検討を要する。天井吹出空調を用いた場合 は上下方向の局所空気䱽の差がわずかしかみられなかった。

トレーサーガスは点Dに設置したサーマルマネキンのロ元から ドーズした。全面床吹出置換空調を用いた場合の床上 $1.2 \mathrm{~m}$ の高さ のトレーサーガス濃度はほほ $5 \mathrm{ppm}$ 以下であり非常に低かった。し かし、床上 $0.1 \mathrm{~m}$ と $2.4 \mathrm{~m}$ の高さではより高い濃度を示し、変動した。 おそらくこれは $\mathrm{SF}_{6}$ がコールドガスであるためドーズした位置より 下部の空気と混合したためと考えられる。壁吹出置換空調を用いた 場合は床上 $1.2 \mathrm{~m}$ の高さのトレーサーガス濃度はあまり低くはなか った。これはこの高さより下部の比較的高めの風速や存在したであ ろう下向気流による影響であると考えられる。天井吹出空調を用い た場合は、上下 3 点のトレーサーガス濃度は 10-20ppm となり比較 的均一であった。

\section{4. ティスカッション}

全面床吹出置換空調は床全面からの吹出しを行うことにより、高 熱負荷処理のために大風量を吹出す場合でも床上の風速を低く抑 えることができる。このシステムを用いた場合の通気性カーペット 両面の $1{ }^{\circ} \mathrm{C}$ 前後の温度差は、室内熱負荷の一部を対流だけでなく熱 伝導により処理し得ることを示している。

\section{5. 耤詅}

全面床吹出置換空調と壁吹出置換空調を用いた場合には、天井吹 出空調を用いた場合と比べて室内下部と上部との間に大きな温度 差がみられ、温度成層が確認された。全面床吹出置換空調と壁吹出 置換空調を用いた場合、「800m $\left.3 / \mathrm{h} 、 25 \mathrm{~W} / \mathrm{m}^{2}\right\rfloor$ の条件下でのみ ASHRAE 55-1992 の上下温度差の推奖值の条件を満たした。 $「 800 \mathrm{~m}^{3} / \mathrm{h}$ 、 $50 \mathrm{~W} / \mathrm{m}^{2} 」$ の条件以外では、全面床吹出置換空調を用いた場合の方が 壁吹出置換空調を用いた場合よりも垂直温度分布が大きかった。全 面床吹出置換空調を用いた場合は上下方向の各計測点における気 流は $0.1 \mathrm{~m} / \mathrm{s}$ 以下の低風速であった。これと比較して、壁吹出置換 空調を用いた場合には、床近傍においてかなり風速が高くなった。 全面床吹出置換空調と壁吹出置換空調を用いた場合、サーマルマネ キンの腰以外の皮唐温度は、天井吹出空調を用いた場合よりやや低 かった。全面床吹出置換空調を用いた場合、他のシステムと比較し て、特に部屋下部における局所空気齢が低くなった。

(1996年12月10日原稿受理，1997年5月6日採用決定) 